\title{
German Theater at Northern American Colleges and Universities 1992 - 2006
}

A Survey ${ }^{1}$

\section{Bettina Matthias}

1. This article is an extended version of a paper that I presented at the 2007 ACTFL annual convention in San Antonio, Texas.

\begin{abstract}
This article presents results from the latest survey on German theater at Northern American colleges and universities. The survey covers the period since the last such query in 1991 until 2006. It assesses a growth in theater productions in German and the logistics surrounding them, and it lists the most performed plays and the most popular authors performed. Finally, the article identifies areas of concern for those working in German theater at academic institutions and invites interested colleagues to join a newly established network that serves to facilitate the exchange of ideas, cooperation, and recognition of foreign language theater as a key contribution to a language program's offerings.
\end{abstract}

\section{Introduction}

The past fifteen to twenty years have seen a noticeable increase in scholarly publications about theater- and drama-based foreign language teaching. Just a cursory look at the extensive research bibliography of Scenario identifies the years since the early 1990s as very productive ones in this field, and more recent contributions, like Manfred Schewe's many publications on "theaterpädagogisches Lehren und Lernen" (drama-based teaching and learning), Gerd Bräuer's edited volume Body and Language: Intercultural Learning Through Drama (Bräuer 2002), and the first in-depth assessmentbased study of the effects of play productions on students' proficiency in the foreign language, conducted by Colleen Ryan-Scheutz and Laura Colangelo ${ }^{2}$ in 2004, have shown new and exciting directions in which this interactive and creative approach to teaching could lead.

\footnotetext{
2 Ryan-Scheutz, Colleen, and Laura Colangelo, "Full-Scale Theater Production and Foreign Language Learning" (2004).
} 
Given such intensified attention to using theater-and drama-based approaches in foreign language teaching, the question arises whether this scholarly interest is coupled with an equal increase in practical drama-related activities at institutions of (higher) learning. Drama-in-education, that is, exercises and creative explorations of situations that are derived from actors' training routines (improvisations, role-plays, tableaux vivants etc.) have certainly become common techniques in the communicative language classroom, and they are part of most every good textbook's suggestions for semi-guided or open-ended work for students. In that respect, practice and theory seem very much in line.

However, theater in a foreign language, in other words, the staging of scripted dramatic scenes or full plays, to be performed in front of an audience, is less common an offering in a foreign language program's curriculum or "co-curriculum" but is, I maintain, on the rise as an alternative to traditional approaches to teaching literature and culture. Considering the required language skills for such a production, foreign language plays can less often be found in secondary schools. ${ }^{3}$ My report is thus concerned with theater productions at colleges and universities in the U.S. and Canada. ${ }^{4}$ And since my own background, both as a scholar and as a practitioner, is in German theater, I will focus on the situation in German. I hope that colleagues from other languages will conduct similar surveys in order for the entire community of foreign language theater practitioners to get a more complete picture of what is happening around us and understand our work as part of a bigger effort to bring our languages and their cultural products to the attention of a broader community of learners and "consumers."

Finally, I would also like this article to be understood as an incentive for everybody interested in German theater to join a newly established network of colleagues called "Arbeitsgruppe Deutsches Theater Nordamerika" (ADTA), currently in its first phase as a listserver, supported by Middlebury College in VT. ${ }^{5}$ Given the results from the survey on which this article reports, there should be enough interest in German theater and its framework to start a productive and lively exchange of ideas and concerns via this venue. Ideally, such a forum could encourage collaborative projects and help push for more institutional and structural support for colleagues who struggle to realize their theater projects, and for younger colleagues to be trained appropriately in order to contribute successfully to their program's offerings.

If my survey of German theater activity at colleges and universities in the U.S. and Canada shows one particular development, it is that there is a noticeable

\footnotetext{
${ }^{3}$ Comprehensive data on foreign language plays at middle and high schools are not available at this point. Of course there are many colleagues at those schools who produce little skits etc. in the language they teach. However, longer foreign-language theater productions are probably the exception at those institutions, unless they are bilingual schools (mainly for Spanish speakers).

${ }^{4}$ Since I received only two responses from Canada, this report is mainly concerned with theater at U.S. colleges and universities.

5 To sign up for this listserver, please visit http://www.middlebury.edu/services/lists/ subscribe.aspx and check the box "adta."
} 
trend towards offering annual or bi-annual courses whose main goal is the academically informed production and staging of a dramatic work. Offering these classes may be part of many departments' efforts to increase enrollment; ${ }^{6}$ more importantly, it is a creative and engaging way to restructure and rethink a department's offerings in language, literature and culture at a time when professional discussions at the highest levels call for the abandonment of traditional literature-based curricula and challenge us to find more modern, interactive and cultural proficiency-oriented ways to teach our students. ${ }^{7}$

My survey, which assesses German theater activity in Northern America between 1992 and 2006, picks up where the last such published survey, Astrid Ronke's "Theaterspielen als didaktisches Mittel im Fremdsprachenunterricht" (Ronke, 1993) ${ }^{8}$ left off. Whereas she still had to send her survey by regular mail, probably making her initial work very time- and cost-intensive, I could send my inquiry by e-mail, potentially reaching a higher number of colleagues and programs in virtually no time. However, this benefit also had its drawbacks since many institutions' spam filters rejected my mass-mailing, more often than not without notifying me of this blocking action. Given these circumstances, percentage points reported in my statistics will thus be based mainly on the number of responses and not the total number of German programs in the country, and information provided in this article should be understood as an indicator of trends, continuities, and discontinuities - but a very strong indicator as many of the comments I received suggest.

\footnotetext{
${ }^{6}$ Some respondents to my query mentioned the desire to increase enrollments as one of the goals when offering theater-based courses. See, for example, the following statements: "I see it as a recruitment effort as well: to encourage lower-level students to go on with German and connect to the literature better through performance. It also promotes a better sense of community among students and faculty" (response from UCLA). "It [= the play production] instilled a great sense of accomplishment in the students and was a source of advertisement for the German Program" (response from Bishops University, Canada). "We've done this [= offering a play as a course] twice now (Spring 04 and Spring 06), and because of the interest it generated both times among students and German-speakers in the community in general, we will schedule another play in Spring 08" (response from the University of Nevada-Las Vegas).

7 The MLA Ad Hoc Committee on Foreign Languages was charged to study the current condition and health of language departments across the nation and came out with their nowfamous call for a radical change of direction at the 2006 MLA Convention in Philadelphia. Their report "Foreign Languages and Higher Education: New Structures for a Changed World" is available on the MLA homepage at http://www.mla.org/flreport. Reactions to their findings and suggestions were strong and have been ongoing in various publications and media.

${ }^{8}$ Astrid Ronke, "Theaterspielen als didaktisches Mittel im Fremdsprachenunterricht: Ergebnisse einer Umfrage an amerikanischen und kanadischen Universitäten und Colleges" (1993). Ronke continued her research on theater at American institutions of higher learning with her dissertation at the TU Berlin ("Alles Theater" 2005) but has not published a summary of her more detailed findings beyond the TU's website. Her survey, conducted in late 1991, continued a tradition that started with Horst Richardson's "German Play Production in U.S. and Canadian Colleges and Universities Since 1959," (1974). His account was followed by Jürgen Schlunk's "Play Production in German Departments of U.S. and Canadian Colleges and Universities from 1973-1988" (1990).
} 


\section{The Survey}

\subsection{The Survey and Its Questions}

Guided by some of the most important questions that previous surveys had raised, by my own interest in the way colleagues go about theater, and also by a desire to keep the first round of data nicely small and compact, I sent a first query with only four questions. They were:

1. How many full-scale shows have you done over the past 10-15 years (if any) ${ }^{9}$

2. Who was in charge of these productions? (you, your colleagues, grad students, undergrads)

3. (If possible) What plays did you stage?

4. How were these productions funded and received?

After I had received a good number of responses in which some of the respondents had already touched upon the issue of language proficiency and projects involving students from lower-level courses, I sent two follow-up questions to those colleagues who had reported theater activity at their institutions. These two additional questions were:

1. What level of German did students participating in productions have?

2. Generally speaking: What roles did those with less German have?

When I sorted through the responses, I developed a second set of questions that would guide my analysis of the data that I had received. While the survey questions seemed to work well as prompters for colleagues to send detailed and very informative answers, they did not suffice to discuss some of the issues involved in theater that are less easily quantifiable and thus did not make it into my set of survey questions. As the following analysis and discussion will show, colleagues also commented on pedagogical and logistical issues beyond the scope of the survey questions in the narrower sense, and they mentioned concerns and specific problems that should be spelled out instead of being squeezed into percentage points and statistical information. The following six issues crystallized as I worked through my data:

1. How active are programs with regards to German theater? How popular is such an activity in general?

\footnotetext{
${ }^{9}$ Most everybody reported on a longer time frame than the past 15 years, and where information on the past 15 years - instead of ten - was missing, I sent an individual follow-up or researched the information pertaining to the years after 1992 on departmental homepages. The following results reflect activity over the past 15 years as much as respondents could account for it.
} 
2. How do programs and departments go about the production of a play?

3. Where are the centers of German theater in North America, and what plays and authors are performed?

4. Why do programs and departments offer theater?

5. What are the outcomes, both pedagogically and institutionally speaking? ${ }^{10}$

6. Where and how should we get more active and secure or provide more support?

In retrospect, one could argue that I could as well have sent a version of these questions in the first place, but this is the fate of any query that one devises: the results should often be in before we know what questions we should ask.

\subsection{The Method}

I first sent my query by e-mail to colleagues through the Women in German (WIG) listserver (October $30^{\text {th }}$ 2006). In order to reach more than this listerserver's $400+$ subscribers, I re-sent the same query to 1165 colleagues listed as members of the American Association of Teachers of German (AATG) on November $3^{\text {rd }} 2006$, hoping to reach all of the German programs that are currently active. According to the last official count published in Monatshefte (2000), this number should be 589 German programs in the U.S. and Canada. ${ }^{11}$ Even though this information is rather outdated, I will have to use it since neither the MLA nor AATG were able to provide a more recent count.

After gathering all of my information and asking for further clarification where and when warranted, I sent my two follow-up questions to everybody who had reported theater activity between 1992 and 2006 in early May 2007 and received eight more responses to these questions. I concluded my collection of data in August 2007 and presented my findings during one of the AATG-sponsored sessions at the ACTFL annual convention in San Antonio in mid-November 2007.

\footnotetext{
${ }^{10}$ It was and could not be the purpose of my query to provide specific, that is: assessmentbased information on pedagogical goals and outcomes. In order to do so, colleagues would have had to use a common set of assessment tools and measures (for example to measure changes in the students' language proficiency, literary-critical skills or pronunciation). Unfortunately, such a set is not yet available as much as it would help us make a case for the effectiveness of theater-based instruction. To my knowledge, there is only one study that provides an empirical, assessment-based discussion of theater in foreign language education (in their case: Italian), Colleen Ryan-Scheutz' and Laura Colangelo's, "Full-Scale Theater Production and Foreign Language Learning" (2004). More studies of this nature should be conducted to provide stronger data and possibly evidence of theater's effectiveness to further students' learning.

11 The MLA recently published a report on enrollment in German nationwide in 2006 (MLA 2007). In this document, they list a total of 898 four-year institutions in the U.S. at which students took German. There is no information on how many actual programs and departments there are in the country. A now-defunct website (www . uscolleges.org) listed 410 German programs and departments in the U.S. when I did my initial research in summer 2007. However, this number cannot be verified and will thus not be used for calculations.
} 


\subsection{Return Rate and General Data}

Given the aforementioned problems caused by spam filters that do not always notify the sender of their action, I have no data on how many colleagues I did indeed reach. Of those whom I reached, 149 colleagues/ programs responded by e-mail ${ }^{12}$ (accounting for $25.61 \%$ of the 589 programs listed in 2000). Most everyone reporting no activity did so in just one line; eight colleagues took the time to expand further on why they do not offer German theater (anymore). 86 programs reported having produced at least one German play over the past 15 years $(14.6 \%)$. Six of these responses reported having produced German plays in translations, thus leaving 80 schools/ programs that have produced either scenes or full-scale plays in German over the past 15 years $(=13.6 \%)$. Five of these programs are summer programs and programs abroad, lowering the total number of regular schools offering German theater to $75(=12.7 \%$ of all programs listed in 2000). Still, considering that in 1991, only 55 programs and departments had reported having engaged in theater projects in the period covered by Ronke's survey, this increase of 20 schools means a total statistical growth of $36.4 \%$ within 15 years!

\section{Results}

\subsection{How Often and Where? Popularity}

Of the 75 schools reporting German theater over the past 15 years, 20 of them, or $27 \%$, have offered annual or bi-annual theater-based courses, often called "German Theater Workshop." Six schools offer such a class less often (every three/four years or less) but have it in their course catalogue, making the total number of programs offering a theater-focused class 26 , or $35.1 \%$ of all schools doing plays. A number of these (bi-)annual courses have been added to the curriculum since the year 2000 (University of Washington: 2000; University of South Carolina: 2000; University of California, Los Angeles: 2003; University of of Nevada-Las Vegas: 2004; Middlebury College: 2004; University of Kentucky: 2005; John Carroll University: 2006), other schools (including: University of Oregon, University of Virginia, Connecticut College, University of Texas, Austin, University of Wisconsin-Madison, University of Minnesota, Wooster College, Miami University of Ohio, Wesleyan University and Gettysburg College) have had these courses on the books for a (long) while, and four colleagues reported the loss of such a course due to budgetary cuts and staffing problems (however, the course still exists in theory). $40 \%$ of all schools having produced at least one play between 1992 and 2006 have thus done so in the context of a special class.

\footnotetext{
12 Ronke reports a return rate of $70 \%$ ( $=213$ responses) to her query which she had sent to 309 institutions in late 1991 (Ronke, 1993: 211). The traditional way of sending a questionnaire by mail may have been more conducive to receiving answers. But considering the massive amounts of mail that we receive every day in language departments these days in which such a paper questionnaire could easily disappear, I opted for the less expensive and less time-intensive e-mail query, accepting its drawbacks as stated above.
} 
Two schools reported doing plays both in the context of a (bi-)annual class and as a regular extra-curricular activity (theater group), thus offering regular annual plays on their campuses. In total, there are twelve schools $(=16 \%$ of all schools doing plays) that have offered theater outside the context of a class, five of them produce plays on a regular basis. Two special programs worth mentioning: Colorado College's theater group has the longest tradition, going back to the 1960s, and the University of Michigan's Residential College, under the direction of Janet Hegman Shier, started their special and intensive work with German theater in the 1980s. ${ }^{13}$ Established German theater groups perform plays on an annual basis (two schools even reported doing a show per semester when possible), one school does a play every other year, one school can do so every four years, and six schools offer plays whenever possible (no regular schedule).

All other schools not offering a special theater workshop or an extra-curricular theater group have made the performance of a play or scenes from a play a part of their literature and culture courses. Considering that only ten schools have never integrated theater into their courses, and seeing that at least seven schools have added a theater-based course to their catalogue since 2000, it is safe to say that theater-based approaches to teaching literature and culture have indeed become more accepted and more employed by institutions nation-wide, and this trend might possibly indicate a change in our profession's definition of self as far as our work with students is concerned.

\subsection{How Do Schools Go about the Production of a Play? Logistics}

So far, I have not made a distinction between the production and performance of full-scale plays and scenes. There are 11 schools that reported shorter productions of skits and scenes of about 20 minutes, often edited and/or written by students in the class. Several of these skit-nights were produced and presented by students in first and second year classes; most full-evening performances, on the other hand, were presented by students from upper level courses ( $5^{\text {th }}$ semester and upwards), with extras recruited from lower level classes without credit. Two schools offered theater classes as multi-level courses. Where and when a full play was staged outside the context of a class, the cast featured students from all levels, including graduate students where applicable. Upper-level students normally took on the longer and more difficult roles while students from lower-level classes acted in supporting roles (only two schools reported an exception from this rule).

Of the 64 schools reporting full-evening performances, three schools have performed cabarets (a collection of scenes, skits and self-written mini-plays), one school has staged an annual reader's theater event, two schools have

\footnotetext{
13 For more information on Hegman Shier's UMIRC Deutsches Theater and its theoretical framework, please consult: Janet Hegman Shier, "The Arts and the Foreign/Second Language Curriculum: An Interdisciplinary Approach to Actively Engage Students in Their Own Learning" (2002).
} 
performed a number of puppet plays (including Faust), and 58 schools have produced full plays over the past 15 years $(=77.3 \%$ of all schools reporting theater activity in German).

All course-related productions are directed by the professor/instructor of the course (who could also be an advanced graduate student); in several cases, professors are helped by graduate or undergraduate teaching assistants or a German teaching assistant. Six schools have had a professional director from Germany in residence to produce their plays in the context of a special class. The University of Wisconsin-Madison has been able to host professional director Manfred Roth every other year to work on a production with their students.

In terms of the logistics of producing a play, I received the following information: ${ }^{14}$

1. Only four schools reported doing auditions for their plays, one school had members of the theater department present at auditions.

2. Almost all colleagues emphasized how much they profited from help provided by the theater department at their school, ranging from getting costumes and rehearsal space to procuring help with sets, lights, and sounds, including staff support, to two instances when the theater department provided substantial financial support. Collaboration between foreign language departments and theater departments seems to have improved since Ronke's report. ${ }^{15}$

3. A production normally runs for a term when it is (part of) a course. In theater groups or when done as a special project, production time varies from one term to six months to a full academic year.

4. Plays are either performed in large classrooms and multi-purpose rooms (ten schools), auditoria/lecture halls (nine schools), in a real theater (six schools), and in one instance, annual skit-night got performed in the college's German House as part of their "Kaffeeklatsch." Two schools reported having a special theater for foreign language/ German theater.

5. Funding has mostly come from departmental budgets (25 responses), sometimes with additional support from the German Club (three responses). Special institutional support was available to eight colleagues, four could take advantage of special grants and/or support from the Goethe Institut, AATG, the Max Kade Foundation or local grants, three productions were funded with the help of private fund-raising efforts or through a special fee for the course, and two times, the theater program's budget helped out. Only two schools reported charging a modest admission fee.

\footnotetext{
${ }^{14}$ Since I did not ask for detailed information on some of these points, the numbers in this section do not line up with the total number of positive responses. However, the information that my colleagues volunteered is compelling enough to deserve mention.

15 In her report, Ronke states: "Nur 13 Abteilungen berichten von einer positiven Kooperation mit der Theaterabteilung (also 24\%) ..." (Ronke 1993: 212).
} 
6. The majority of productions were not very cost-intensive. 13 colleagues reported having no major expenses (except for posters and programs); three schools spent under $\$ 100$ on their shows, another three schools spent under $\$ 200$, and only five schools spent more than $\$ 200$ - however, not many colleagues provided concrete numbers.

7. Of the 38 respondents able to provide reliable information, 17 reported having done one performance per show; 13 schools opted for two performances per show, and nine schools had three or more performances. Except for two colleagues, all respondents reported an enthusiastic audience - and audience sizes were mostly rewarding: Only three schools had very small audiences, six estimated their crowds between 50 and 100, and 15 colleagues reported performing in front of more than 150 people in all performances combined. Where audiences were bigger, they included not just members of the German community on campus (students, faculty, staff), but also interested members from the German-speaking (or interested) community at large as well as the cast members' friends and family.

\subsection{The Centers of German Theater in Northern America}

Annual and bi-annual theater-based classes have helped many schools offering German plays on a regular basis. However, extra-curricular theater groups are equally productive: The University of Michigan's Residential College Deutsches Theater (only partly a class) has offered 15 plays over the past 15 years, Colorado College (not a class) has produced an (almost) annual play since 1962, and Miami University's annual Cabaret has seen 14 productions. For a more complete list of schools and their activities, please refer to the table in Appendix A.

Of special mention are the so-called annual "Theaterfeste" hosted by Mount Holyoke College (since 1978), Valparaiso University (since 2003), and the San Diego chapter of AATG (since 2007). These institutions (and as far as I know: others across the country) welcome student groups from elementary schools through college to their campus once a year to have a full day of short performances that compete against each other in a friendly manner. Institutions such as the Goethe Institute or the region's German Consulate General support these events and allow the organizers to promote German theater in a meaningful and appropriate manner.

\subsection{What Authors and What Plays?}

For various reasons, there is very little movement in the "hitlist" of plays performed at colleges and universities. ${ }^{16}$ As in the past two surveys,

\footnotetext{
16 Since none of the respondents commented on their choice of plays in a more detailed manner, I can only speculate on the reasons behind this apparent "conservatism" and offer my
} 
Bertolt Brecht is the most popular author (31 full-length productions, 16 plays performed in full or scenes), followed by Swiss playwright Friedrich Dürrenmatt (20 full-length productions, 4 different plays performed in full or scenes) who held the third position in Ronke's 1991-survey, but the second in the previous one. The third most popular author - and maybe the only surprise in this new survey - is now Austrian Arthur Schnitzler (13 full-length productions, 4 different plays performed in full or scenes) who had held the seventh position back in 1991. In fourth position is Swiss Max Frisch, who was second in 1991 (11 full-length productions, 2 different plays performed in full or scenes), Georg Büchner's works have seen ten full-length productions (position 5 in 1991).

The most popular plays of the last 15 years were:

\section{Biedermann und die Brandstifter (Frisch): 9 (+ 2 x scenes) [1991: \#1]}

2. Die Physiker (Dürrenmatt): 9

3. Woyzeck (Büchner): 8 (+ 2 x scenes) [1991: \#2]

4. Der Besuch der alten Dame (Dürrenmatt): 8 (+ 2 x scenes) [1991: \#3]

5. Die Dreigroschenoper (Brecht/ Weill): 6 (+ 1 x scenes)

6. Reigen (Schnitzler): 5 ( + one adaptation)

A more complete list of popular plays can be found in Appendix B.

\subsection{Rationale for Offering Theater}

Reasons for offering theater are hard to quantify, and only recently have scholars started to conduct systematic empirical studies that assess the usefulness and success of theater as a tool in teaching language, culture and literature. ${ }^{17}$ In my

\footnotetext{
personal considerations when choosing a play for my group. Many modern literary plays are written in a language that is very hard to understand, especially for the audience. Language itself is often part of the dramatic action, of the conflict, is quite often the topic of the play, and even if audiences were able to understand the basic linguistic gist, the cultural framework in which these plays need to be performed and understood is hard to mount outside of the German speaking countries (a case in point: Ernst Jandl's plays). Furthermore, many modern German plays ask for either very small casts of two or three actors, or gigantic ones that no German program could fill. Choosing plays that are well-established (and that others have done before), with well delineated plots and action, possibly including special (and exciting, as far as students are concerned) costumes, sets, and lights, makes a production run more smoothly and allows those involved a greater sense of accomplishment than when they are part of a play that nobody knows, that is hard to access - and that stretches their abilities to the maximum. One play that I can highly recommend to those interested in doing a contemporary play: Ephraim Kishon's comedy Zieh den Stecker raus, das Wasser kocht. This play, though initially written in Hebrew, has been a great success on German stages, and it works extremely well with nonnative student groups.

17 Eoin Bourke's article „Work in the Coalface“ (Schewe/ Shaw 1993) marked the beginning of such empirical work, but only few colleagues have carried further his important work.
} 
survey, many colleagues offered their personal reasons and beliefs for investing so much time and energy in this project. The University of South Carolina's German department summarizes the main pedagogical goals mentioned by many as follows:

[The goal of the course "German Cabaret" is immersion into the German language and culture through involvement with theatre production and performance. The analysis, discussion, adaptation and memorization of mainly literary texts . . . will increase students' reading, speaking, writing, and interpersonal skills, while also introducing their ability to 'relate' to German in social settings. Additional emphasis is put on aspects and practices of German pronunciation and enunciation. ${ }^{18}$

In addition to these pedagogical benefits, colleagues have emphasized that theater is an excellent tool for recruitment and retention, for outreach to the local high schools and the community at large, and a "morale booster" (UC Davis) for departments, students, and faculty alike. Colleagues wrote:

- "To participating students, the experience is tremendously invigorating and inspiring. That's why we keep doing it." (Illinois College)

- "Student feedback has always been super positive about this kind of course. The students feel that their German really improves (especially Vocab building and Aussprache). They seem to bond in a lasting way . . . . I chose to teach this course at Western because I think it is a fantastic outreach and promotion venue." (Western Oregon University)

- "The class is popular and helps to recruit and retain students." (Connecticut College)

- "The play helped to establish the reputation of the department with the community." (University of Tennessee)

- "[Our plays] have encouraged the best efforts of our students, and many said they became majors at least partly on the basis of this experience. The course has been a great success and a stimulating learning experience for everyone involved." (College of Wooster)

Only one colleague wrote that doing plays had neither been a rewarding nor a successful project in terms of recruitment or retention since time issues had become too difficult to overcome.

However, this was just one isolated voice of dissent in what has otherwise been a uniformly positive assessment of theater in German programs. Even those colleagues who could not or cannot do plays for reasons discussed in the next section emphasized their belief in foreign language theater, best expressed

\footnotetext{
18 Thus quoted in an e-mail from Professor Michael Buerstner, German Studies Program, University of South Carolina, October $31^{\text {st }} 2006$.
} 
by one colleague from Duke University, who wrote: "We have not done [plays] in several years, mostly because of the 'Zeitaufwand' and the lack of someone with acting/directing expertise. However, I would very much like to do it again in the future, because I really believe in the educational value of such an endeavor, not to mention the benefits for language acquisition!"

\section{Further Considerations: Problems and Solutions}

As I mentioned earlier, eight respondents who reported no theater at their institution elaborated a little further on the reasons behind this lack of dramatic activity, and several other respondents also discussed briefly the problems associated with these projects. Budgetary constraints are certainly one issue, but considering that many colleagues can make their plays and scene work with very little, the main reason must lie elsewhere. Theater projects are very time-consuming for everybody involved - much more so than a regular class. Students at bigger schools, who have to commute to campus and hold jobs in addition to being students, may be hard to gather; but an even graver problem exists for the instructor of such a class or production. So far, neither all colleagues nor all institutions - nor our profession, for that matter - have accepted and embraced working in and on theater productions as important professional contributions. As one respondent put it, "[a play production] does not count for a publication in our field and so the net effect is that the professor putting energies into play productions might be penalized (for writing one less article, etc.)." Other colleagues have echoed this concern, and it is here that we, as a group of people involved in a very worthy educational mission, should and maybe could get more active and push for a rethinking of traditional values in our professional environment. While not a publication and maybe a little less research-intensive than an article that we want to submit as a major publication, work in foreign language theater still requires our full attention as scholars and researchers. Besides being a significant contribution to the areas of teaching and service to the college, it also reaches beyond the campus and promotes not only the study of German (in our case), but also the active and critical engagement with texts and other cultural products to a wider community. Leading a group of students through all the phases involved in producing a successful play is a task that requires knowledge, leadership, and a vision, and institutions should recognize the value of such an endeavor in terms of tenure requirements/ contract negotiations.

Furthermore, as the survey shows, more and more departments seem to integrate theater-based courses in their offerings to respond to recently identified challenges in our profession. Training the next generation of teachers to include this special approach to teaching would thus be an additional way of preparing young colleagues for successful job searches and careers in the field. 


\section{Conclusion}

This newest survey has confirmed the timeless popularity of several early to mid-twentieth century playwrights, has identified the big stages for German theater in the United States, has once again proven the tireless commitment of many colleagues to offer our students most memorable and popular educational experiences without draining their school's budget too much, and it has pointed out the most likely student groups to participate in (full-scale) theater projects. In that respect, my query identifies trends and phenomena that my predecessors have already assessed. However, the fact that at least seven well-established schools have recently added a (bi-)annual course on German theater "in action" could indicate a trend towards embracing theater as a valid and important departmental offering. Course descriptions for such courses make it very clear that theater workshops consist of much more than just rehearsals and performances. Students engage in significant - and meaningful! - research tasks, take responsibility for their work with a text and their use of the foreign language, and they understand drama as a complex work of art that requires multiple intelligences and interdisciplinary thinking. What is more, they also learn how to negotiate and collaborate in an intensive environment, making the production of the play even more important than its final performance. In addition to their many linguistic benefits, theater productions help recruit and retain students, reach out to the community and make our language programs more visible and possibly more interesting. Last but not least, theater is a very different, active, and very enjoyable way for our students to experience literature and to learn how to work in-depth on one piece of literature for a long time, something for which we rarely have time in traditional courses. It is all of these qualities that many colleagues have come to recognize as unique opportunities and that have contributed to our, the practitioners', belief that there is hardly a more effective way to reach and meet students halfway in their efforts to study literature, language, and culture. As this newest survey shows, more and more colleagues and schools have come to embrace this less traditional and somewhat adventurous approach to engaging our students with the material they study. Let us hope that more will follow and that concerns, such as those voiced by colleagues plagued by the stresses of tenure and contract renewals, will eventually become issues about which no one willing to direct theater productions will have to worry.

\section{Bibliography}

Bourke, Eoin (1993): Work in the Coalface: An Empirical Approach to Foreign Language Theater for Students. In: Schewe, Manfred / Shaw, Peter (eds.): Towards Drama as a Method in the Foreign Language Classroom. Frankfurt/M.: Peter Lang, 227-248 
Bräuer, Gerd (ed.) (2002): Body and Language. Intercultural Learning Through Drama. Westport, CT: Ablex

Dodd, Nigel / Hickson, Winifred (eds.) (1971): Drama and Theatre in Education. London: Heinemann

Cafferty, Helen (1982): German-Language Play Production as Cultural Mediation." In: Die Unterrichtspraxis, 15/2, 240-243

FitzGibbon, Emilie (1993). Language at Play: Drama and Theater in Education as Stimuli in Language Learning. In: Schewe, Manfred / Shaw, Peter (eds.): Towards Drama as a Method in the Foreign Language Classroom. Frankfurt/M.: Peter D. Lang, 249-268

Haggstrom, Margaret (1992): A Performative Approach to the Study of Theater: Bridging the Gap between Language and Literature Courses. In: The French Review 66/1, 7-19

Hegman Shier, Janet (2002): The Arts and the Foreign/Second Language Curriculum: An Interdisciplinary Approach to Actively Engage Students in Their Learning. In: Bräuer, Gerd (ed.) (2002): Body and Language, Intercultural Learning Through Drama. Westport, CT: Ablex, 183-206

Kramsch, Claire / Kramsch, Olivier (2000): The Avatars of Literature in Language Study. In: The Modern Language Journal 84/4, 553-573

Lederer, Herbert (1981): The Play's the Thing: The Use of Theater in Language Teaching. In: Studies in Language Learning 3/2, 35-41

Modern Language Association (2006): Foreign Languages and Higher Education: New Structures for a Changed World. Accessed at: <http://www.mla.org/flreport>06.11.08

Modern Language Association (2007): Fall 2006 Enrollment in German. In: Enrollment in Languages Other Than English in United States Institutions of Higher Education, Fall 2006. Accessed at 06.12.2008: <http://www.mla.org/pdf/enrollment/german_2006.pdf>

Richardson, Horst (1974): German Play Production in U.S. and Canadian Colleges and Universities Since 1959. In: Die Unterrichtspraxis 7/1, 142-147.

Ronke, Astrid (1993): Theaterspielen als didaktisches Mittel im Fremdsprachenunterricht: Ergebnisse einer Umfrage an amerikanischen und kanadischen Universitäten und Colleges. In: Die Unterrichtspraxis 26/2, 211-219

Ronke, Astrid. (2005): Wozu all das Theater? Drama and Theater as a Method for Foreign Language Teaching and Learning in Higher Education in the United States. Diss. TU Berlin. Accessed at 06.12.2008: $<$ http://edocs.tu-berlin/de/diss/2005/ronke_astrid.pdf>

Ryan-Scheutz, Colleen / Colangelo, Laura (2004): Full-Scale Theater Production and Foreign Language Learning. In: Foreign Language Annals 37/3, 374-389

Schewe, Manfred (2002): Teaching Foreign Language Literature: Tapping the Students' Bodily-Kinesthetic Intelligence. In: Bräuer, Gerd (ed.) (2002): 
Body and Language, Intercultural Learning Through Drama. Westport, CT: Ablex, 73-93

Schewe, Manfred (1998a): Dramapädagogisch lehren und lernen. In: Jung, Udo O.H. (ed.) (1998): Praktische Handreichung für Fremdsprachenlehrer. Frankfurt/M.: Peter Lang, 334-340

Schewe, Manfred (1998b): Fremdsprache inszenieren. FSU 1/1998: 51-52, FSU 3/1998: 206; FSU 5/1998: 363; FSU 6/1998: 426-427

Schewe, Manfred / Shaw, Peter (eds.) (1993): Towards Drama as a Method in the Foreign Language Classroom. Frankfurt/M.: Peter Lang

Schlunk, Jürgen (1990): Play Production in German Departments of U.S. and Canadian Colleges and Universities from 1973-1988. In: Die Unterrichtspraxis 23/1, 69-75

Schultz, Karla / Heinigk, Penelope (2000): Magic on Stage: Urfaust and Other Great Plays for Educational Pleasure. In: Bräuer, Gerd (ed.), Body and Language, Intercultural Learning Through Drama. Westport, CT: Ablex, 233-239

Smith, Stephen M. (1984): The Theater Arts and the Teaching of Second Languages. Reading, MA: Addison-Wesley

Van Handle, Donna (1988): Developing Proficiency in Context: The Creation and Production of German Plays. In: Die Unterrichtspraxis 21/2, 196-198 


\section{Appendix A}

\section{Centers of German Theater at Northern American Institutions}

\begin{tabular}{|c|c|c|}
\hline School/ Program & $\begin{array}{l}\text { \# of } \\
\text { performances } \\
\text { since } 1992 \\
\end{array}$ & Comments \\
\hline $\begin{array}{l}\text { University of Michigan } \\
\text { Residential College/RC } \\
\text { Deutsches Theater }\end{array}$ & 15 & $\begin{array}{l}\text { Annual event; Janet Hegman Shier } \\
\text { director; special program (class and } \\
\text { group activity),emphasis on Brechtian } \\
\text { theater }\end{array}$ \\
\hline Colorado College & 15 & $\begin{array}{l}\text { Annual play, goes back to the } 1962 \text {, } \\
\text { not for credit }\end{array}$ \\
\hline Miami University of Ohio & 14 & Annual cabaret, now always for credit \\
\hline Brigham Young University & 14 & $\begin{array}{l}\text { Annual Reader's Theater, normally not } \\
\text { for credit }\end{array}$ \\
\hline University of Texas, Austin & 12 & $\begin{array}{l}\text { Often in cooperation with TX } \\
\text { Association of German Studies; most } \\
\text { often a class }\end{array}$ \\
\hline University of Virginia & 8 & Now annual class in spring \\
\hline Middlebury College & 8 & $\begin{array}{l}\text { Mostly extra-curricular; also bi-annual } \\
\text { class since 2004; group started in } \\
2001\end{array}$ \\
\hline University of Wisconsin & 8 & $\begin{array}{l}\text { Bi-annual class, taught by professional } \\
\text { German director Manfred Roth }\end{array}$ \\
\hline University of Oregon & 7 & $\begin{array}{l}\text { Part of a class (on German theater, on } \\
\text { particular author) }\end{array}$ \\
\hline $\begin{array}{l}\text { University of South } \\
\text { Carolina }\end{array}$ & 7 & $\begin{array}{l}\text { Annual cabaret since } 2000 \text {; as a } \\
\text { course }\end{array}$ \\
\hline University of Minnesota & 7 & $\begin{array}{l}\text { Bi-annual class with variable credit (1- } \\
\text { 3) }\end{array}$ \\
\hline
\end{tabular}

- + Wesleyan University: long list of plays, no date assigned, director retired in 2003

- + 6 shows: University of Washington (newer annual class); Wooster College (bi-annual class)

- +5 shows: Gettysburg College (bi-annual class)

- + 4 shows: Ohio State University, Bowling Green State University, Ball State University, University of California, Los Angeles (since 2003), University of Calgary, Calvin College, Rollins College (puppet plays)

- +3 shows: University of California, Davis, Indiana University-Purdue University, Webster University, University of California, Berkeley (Kabarett) 


\section{Appendix B}

\section{Most Popular Plays 1992 - 2006}

1. Die Physiker (Dürrenmatt): 9

2. Biedermann und die Brandstifter (Frisch): 8 (+ 2 x scenes) [1991: \#1]

3. Woyzeck (Büchner): 8 ( +2 x scenes) [1991: \#2]

4. Der Besuch der alten Dame (Dürrenmatt): 8 (+ 2 x scenes) [1991: \#3]

5. Die Dreigroschenoper (Brecht/ Weill): 6 (+ $1 \mathrm{x}$ scenes)

6. Reigen (Schnitzler): 5 ( + one adaptation)

7. Anatol (Schnitzler): 4 ( $+2 \mathrm{x}$ scenes)

8. Die Kleinbürgerhochzeit (Brecht): 4

9. Das heiße Eisen (Fastnachtsspiel): 4

10. Draußen vor der Tür (W. Borchert): 3 (+ 2 x scenes)

11. Frühlingserwachen (F. Wedekind): 3

12. Der grüne Kakadu (Schnitzler): 3

13. Romulus der Große (Dürrenmatt): 3

14. Der gute Mensch von Sezuan (Brecht): 3 